\title{
Merged Digital Aeromagnetic Data for the Middle Rio Grande and Southern Española Basins, New Mexico
}

By Ronald E. Sweeney, V. J. S. Grauch, and Jeffrey D. Phillips

U.S. Geological Survey, MS 964, Federal Center, Denver CO 80225

\section{Open-File Report 02-205}

\section{2}

This report is prelininary and has not been reviewed for conformity with U.S. Geological Survey editorial standards or with the North American Stratigraphic Code. Any use of trade, firm, or product names is for descriptive purposes only and does not imply endorsement by the U.S. Government. 
DISCLAIMERS

\title{
Merged Digital Aeromagnetic Data for the Middle Rio Grande and Southern Española Basins, New Mexico
}

\author{
by \\ Ronald E. Sweeney, V.J.S. Grauch, and Jeffrey D. Phillips
}

Open-File Report 02-205

2002

This publication and online data were prepared by an agency of the United States Government. Neither the United States Government nor any agency thereof nor any of their employees makes any warranty, expressed or implied, or assumes any legal liability or responsibility for the accuracy, completeness, or usefulness of any information, apparatus, product, or process disclosed in this report or represents that its use would not infringe privately owned rights. Reference therein to any specific commercial product, process, or service by trade name, trademark, manufacturer, or otherwise does not constitute or imply its endorsement, recommendation, or favoring by the United Sates Government or any agency thereof.

Although all online data have been used by the USGS, no warranty, expressed or implied, is made by the USGS as to the accuracy of the data and related materials and (or) the functioning of the software. The act of distribution shall not constitute any such warranty, and no responsibility is assumed by the USGS in the use of these data, software, or related materials.

The data contact is: Ronald E. Sweeney

303-236-1389

rsweeney@usgs.gov

U. S. Geological Survey, MS 964

Box 25046, Denver Federal Center

Denver, CO 80225 USA 


\section{INTRODUCTION}

The U. S. Geological Survey (USGS) recently conducted a multi-disciplinary study of the Middle Rio Grande basin (Bartolino and Cole, 2002; Fig. 1). The main purpose of this study was to gain a better multi-dimensional understanding of the basin's hydrogeologic framework and use this new understanding to construct an improved regional ground-water flow model. The Middle Rio Grande basin fill serves as the primary water resource for Albuquerque and surrounding communities (Thorn and others, 1993). It is composed of poorly consolidated, Tertiary to Quaternary sediments, collectively called the Santa Fe Group. These sediments were deposited during the Tertiary to Quaternary development of the Rio Grande rift (Fig. 1, inset). The strata vary in thickness from 1,000 to more than 4,000 m and range from mudstone to conglomerate (Kelley, 1977; May and Russell, 1994).

At the beginning of the Middle Rio Grande basin study, the hydrogeologic framework of the shallow subsurface was poorly known. Two high-resolution aeromagnetic surveys were designed in 1996 (A and B, Fig. 1) to test the utility of the aeromagnetic method for mapping faults and shallowly buried volcanic rocks within the basin fill. This was a non-traditional application of aeromagnetic methods, which previously had been used only for mapping igneous and metamorphic rocks and related basement structures (Nettleton, 1971). High-resolution surveys are flown closer to the ground and with narrower line spacing than conventional aeromagnetic surveys. Resulting maps from the two surveys provided remarkable resolution of faults and igneous rocks within the basin fill (Grauch, 1999; Grauch, 2001; Grauch and others, 2001). The success of the experiment led to further acquisition of high-resolution aeromagnetic data, culminating in 1998 with nearly complete coverage of the Middle Rio Grande basin and extending into the southern Española basin (Fig. 1), a total area of about 8,100 km².

Preliminary grids of the survey data were merged and continued to a surface $100 \mathrm{~m}$ above ground to demonstrate specific magnetic features (Grauch, 1999; Grauch and others, 2001). In this report, we have further refined our data processing procedures to remove artifacts and noise in the original data and give the optimum presentation of the results for interpretation purposes. These procedures are explained in detail, resulting in two products for the study area. The first is a revised grid of the merged total-field aeromagnetic data 


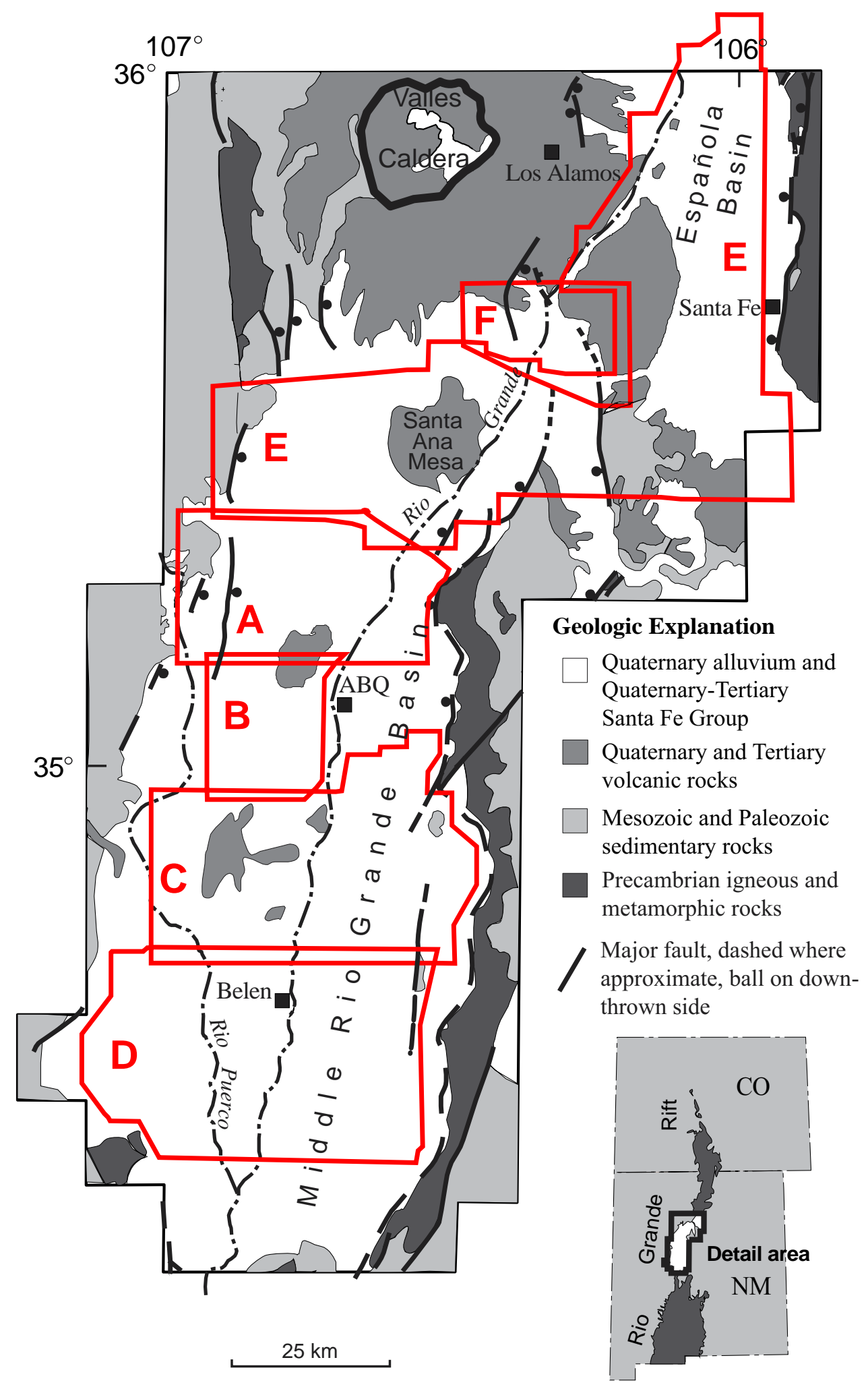

Figure 1. Generalized geology of the Middle Rio Grande and southern Española basins showing the areas covered by the six aeromagnetic surveys (bold red lines) and location of the area within the Rio Grande rift (inset). The letters are keyed to descriptions of the surveys in Table 1. Note the overlap between the survey areas. $A B Q=$ Albuquerque 
observed $100 \mathrm{~m}$ above ground. The second is a grid of reduced-to-pole aeromagnetic data observed $100 \mathrm{~m}$ above ground, which corrects for polarity effects that are typical for aeromagnetic data collected at northern mid-latitudes and generally places local anomalies directly over their sources (Blakely, 1995).

\section{DATA ACQUISITION}

Six high-resolution geophysical surveys were flown during 1996-1998 (Fig. 1):

Rio Rancho (A), Albuquerque West (B), Isleta-Kirtland (C), Belen (D), Sandoval-Santa Fe (E), and Cochiti (F) surveys. All surveys except Cochiti used fixed-wing aircraft with a cesium-vapor magnetometer located in a tail stinger. Magnetic data for the Cochiti survey were collected as part of an airborne time-domain electromagnetic survey using a fixedwing aircraft and towed birds. The specifications and data references for each survey are shown in Table 1. Descriptions of the data acquisition and processing procedures followed by the contractors who conducted the surveys are contained in the data references.

Table 1. Flight specifications of individual aeromagnetic surveys

\begin{tabular}{|c|c|c|c|c|l|}
\hline $\begin{array}{c}\text { Letter } \\
\text { Code }^{1}\end{array}$ & Survey Name & Year Flown & $\begin{array}{c}\text { Line } \\
\text { Spacing }^{2}\end{array}$ & $\begin{array}{c}\text { Terrain } \\
\text { Clearances }^{3}\end{array}$ & \multicolumn{1}{|c|}{ Data Reference $^{4}$} \\
\hline A & Rio Rancho & 1996 & $100 \mathrm{~m}$ & $\begin{array}{c}100 \mathrm{~m} \\
(150 \mathrm{~m})\end{array}$ & $\begin{array}{l}\text { USGS and SIAL, Ltd. } \\
(1997)\end{array}$ \\
\hline B & $\begin{array}{c}\text { Albuquerque } \\
\text { West }\end{array}$ & 1996 & $150 \mathrm{~m}$ & $\begin{array}{c}150 \mathrm{~m} \\
(300 \mathrm{~m})\end{array}$ & $\begin{array}{l}\text { USGS and SIAL, Ltd. } \\
(1997)\end{array}$ \\
\hline C & Isleta-Kirtland & 1997 & $150 \mathrm{~m}$ & $\begin{array}{c}150 \mathrm{~m} \\
(150 \mathrm{~m})\end{array}$ & $\begin{array}{l}\text { USGS and Sander } \\
\text { Geophysics (1998) }\end{array}$ \\
\hline D & Belen & 1998 & $150 \mathrm{~m}$ & $\begin{array}{c}150 \mathrm{~m} \\
(\mathrm{~N} / \mathrm{A})\end{array}$ & $\begin{array}{l}\text { USGS and others } \\
(1999)\end{array}$ \\
\hline E & $\begin{array}{c}\text { Sandoval-Santa } \\
\text { Fe }\end{array}$ & 1998 & $150 \mathrm{~m}$ & $\begin{array}{c}150 \mathrm{~m} \\
(150 \mathrm{~m})\end{array}$ & $\begin{array}{l}\text { USGS and others } \\
(1999)\end{array}$ \\
\hline F & $\begin{array}{c}\text { Cochiti time- } \\
\text { domain EM }\end{array}$ & 1996 & $400 \mathrm{~m}$ & $\begin{array}{c}73 \mathrm{~m} \\
(\mathrm{~N} / \mathrm{A})\end{array}$ & $\begin{array}{l}\text { USGS and others } \\
(1999)\end{array}$ \\
\hline
\end{tabular}

${ }^{1}$ Letter codes refer to areas labeled on Figure 1.

${ }^{2}$ All traverse lines were flown east-west at the spacing listed. Tie lines were flown northsouth at intervals ranging from $3 \mathrm{~km}$ to $10 \mathrm{~km}$.

${ }^{3}$ Terrain clearances are nominal values; draped surfaces were smoother than topography. Values in parentheses indicate nominal clearances over urban areas near Albuquerque and Santa Fe.

${ }^{4}$ Images and information about digital data access can be obtained at the URL address http://rmmcweb.cr.usgs.gov/public/mrgb/airborne.html. 
The Rio Rancho and Albuquerque west surveys (the two experimental surveys) were flown with line spacings and heights above ground of $100 \mathrm{~m}$ and $150 \mathrm{~m}$, respectively. The 1:1 ratio between flight height and line spacing allows adequate sampling of all anomalies across flight lines, including those due to three-dimensional sources at the ground surface, such as cultural features (Reid, 1980). Adequate sampling facilitates application of filters that enhance short-wavelength (spatially limited) features, such as downward continuation, shaded-relief display, and gradient analysis (Reid, 1980). By comparing the results of the two surveys, we realized that the Albuquerque west survey data, which required fewer flight lines and no special permission for flying height, could be downward continued from $150 \mathrm{~m}$ above ground to $100 \mathrm{~m}$ above ground and closely approximate the resolution of the Rio Rancho survey. As a result, all subsequent surveys were specified with a line spacing and height above ground of $150 \mathrm{~m}$, except for the Cochiti survey, which was designed primarily for collection of electromagnetic data. Thus, our ultimate goal, depicted in this report, is to produce a final display of all the data on a surface $100 \mathrm{~m}$ above ground.

\section{MERGED TOTAL FIELD AEROMAGNETIC GRID}

The assembly of the six individual aeromagnetic survey data sets to create the final merged grid was done using a combination of in-house potential field software (Phillips, 1997) and a PC version of Geosoft/OASIS montaj ${ }^{\mathrm{TM}}$. Our strategy for final grid assembly was first to grid the individual survey data, then to continue each of these grids to $100 \mathrm{~m}$ above ground, to filter each grid so as to remove any unwanted noise, and finally, to merge all the grids together. Since our final products include grids of both the residual magnetic field data, continued to our target surface of $100 \mathrm{~m}$ above ground, and the radar-altimeter (terrain clearance) data needed for the continuation, grids of these two data channels were constructed using a minimum curvature gridding algorithm (Webring, 1981). We selected $50 \mathrm{~m}$ as the grid interval for all but the Cochiti survey, where $100 \mathrm{~m}$ was used. The Cochiti grids were subsequently regridded to $50 \mathrm{~m}$ to match the neighboring grids.

For each of the six surveys, the residual magnetic field channel had already been properly corrected using the Definitive Geomagnetic Reference Field by the contractors, so no further main field corrections were necessary before gridding. Likewise, the radaraltimeter channel was used directly for the Rio Rancho and Albuquerque West surveys to 
create the terrain clearance grids, because the more reliable GPS observation elevations were not available. For the Cochiti, Isleta-Kirtland, Sandoval-Santa Fe, and Belen surveys, terrain elevations obtained from a $50 \mathrm{~m}$ terrain grid for the study area were subtracted from the available GPS elevations, and the resultant terrain clearance data were appropriately gridded. The terrain grid was created from a seamless 1:24,000-scale 30-meter Digital Elevation Model (DEM) terrain dataset for the 126-quadrangle Middle Rio Grande basin study area (Hester, 1998). To this we added the 10-meter DEM data for the Bull Canyon, Chili, Chimayo, Galisteo, and San Juan Pueblo quadrangles (U.S. Geological Survey, 2000), located outside the 126-quadrangle area.

All of the residual magnetic field grids were downward continued to a reference surface $100 \mathrm{~m}$ above ground, using the chessboard method of Cordell (1985) as implemented by OASIS Montaj ${ }^{\mathrm{TM}}$. In the chessboard method, the continued data are extrapolated from a series of parallel continuation surfaces that each have been computed using standard Fast Fourier transform (FFT) techniques (e.g., Blakely, 1995). The terrain clearance grids for each of the six surveys determined the distances to continue the data.

To remove any remaining noise related to disparities between flight lines after downward continuation, we applied the decorrugation method of Urquhart (1988), modified for use with a Blackman window (Oppenheim and Schafer, 1975, p. 242). The first step of the decorrugation method is convolution of a Blackman window with the data in the direction of the transverse flight lines, along the grid rows in our case. The convolution is similar in concept to a weighted running average. The convolved data constitute the long-wavelength component, or lowpass grid, and the residual, which is set aside, is the short wavelength component. The same Blackman window is then convolved with the lowpass grid in the direction orthogonal to the flight line direction (along columns). This step is designed to remove the "corrugations" along flight lines. The saved short wavelength component is then added back to this latter filtered grid to restore this component along the flight lines, resulting in the final decorrugated grid.

Several different Blackman windows were tested in each of the six areas. A Blackman window is a cosine-weighted function that tapers from 1 in the center of the window to zero on both ends (Oppenheim and Schafer, 1975, p. 242). The length of the window is specified by the number of non-zero coefficients. Longer filters remove longer 
wavelengths. Table 2 lists optimum filter lengths as a function of flight line spacing, as determined from tests on grids containing sine waves. For all of our six areas, which ranged in line spacing from 2 to 4 grid intervals, the Blackman window of length 11 worked the best, as expected from Table 2. The output grids showed this window to be the shortest we could apply that would remove most of the visible noise while retaining the most geologic signal. Figure 2 compares a test area of data from the $100-\mathrm{m}$ above ground data, containing noticeable anomalous noise, and the final decorrugated data resultant from the application of the Blackman window of length 11.

Table 2. Optimum filter lengths for different flight line spacings as a function of grid interval.

\begin{tabular}{c|c}
$\begin{array}{c}\text { Flight-line } \\
\text { spacing, in grid } \\
\text { intervals }\end{array}$ & $\begin{array}{c}\text { Optimum filter length, } \\
\text { in grid intervals }\end{array}$ \\
\hline 2 & 11 \\
3 & 11 \\
4 & 11 \\
5 & 13 \\
6 & 13 \\
7 & 17 \\
8 & 19 \\
9 & 23 \\
10 & 25
\end{tabular}

The resultant filtered grids were then digitally merged together. The process of merging operates on two grids at a time, and preserves the integrity of the data in the nonoverlap areas of both grids. In the overlap areas, the data are systematically averaged, using a weighting scheme that not only favors the grid we define as the most accurate of the two, but also weights one grid progressively higher than the other as the grid locations in the overlap area grow closer to that grid's boundary. Figure 3 shows the final decorrugated data for the entire Middle Rio Grande basin and southern Española basin study area, after the filtered grids for our six surveys were merged using OASIS montaj ${ }^{\mathrm{TM}}$.

\section{REDUCED-TO-POLE AEROMAGNETIC GRID}

Because magnetic anomalies located away from the north magnetic pole are shifted away from their sources, we performed a reduction-to-pole operation (e.g., Blakely, 1995) 
a) $\square$

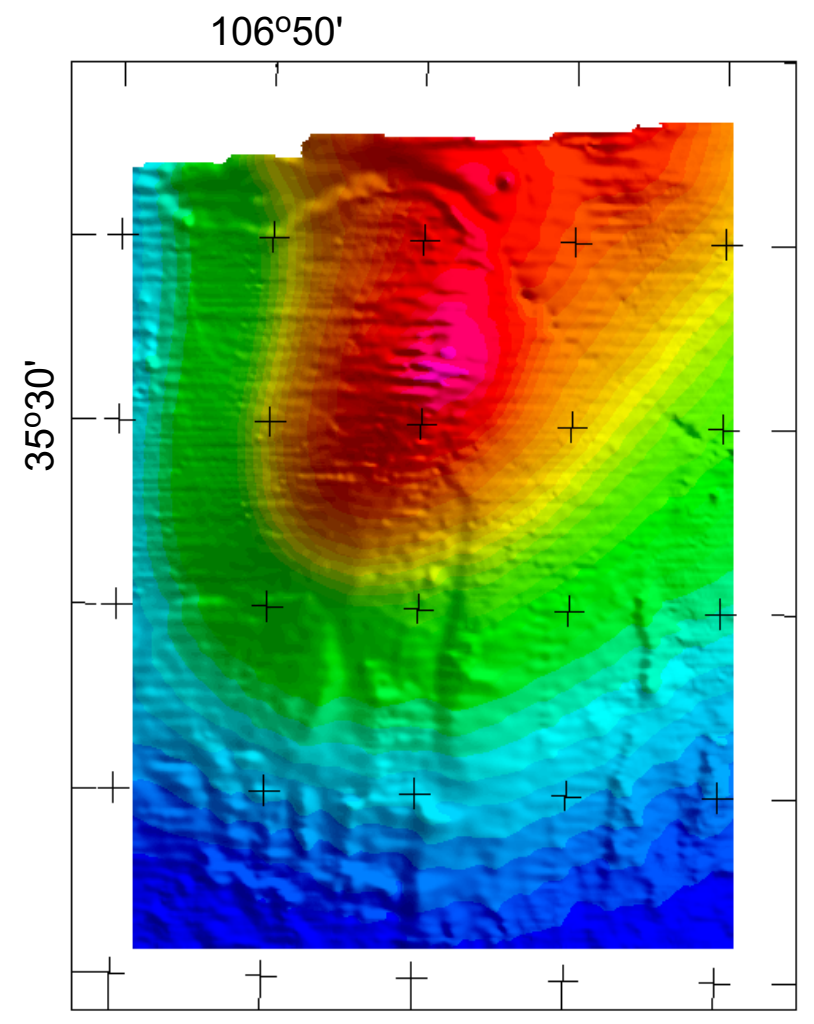

b) $\square$
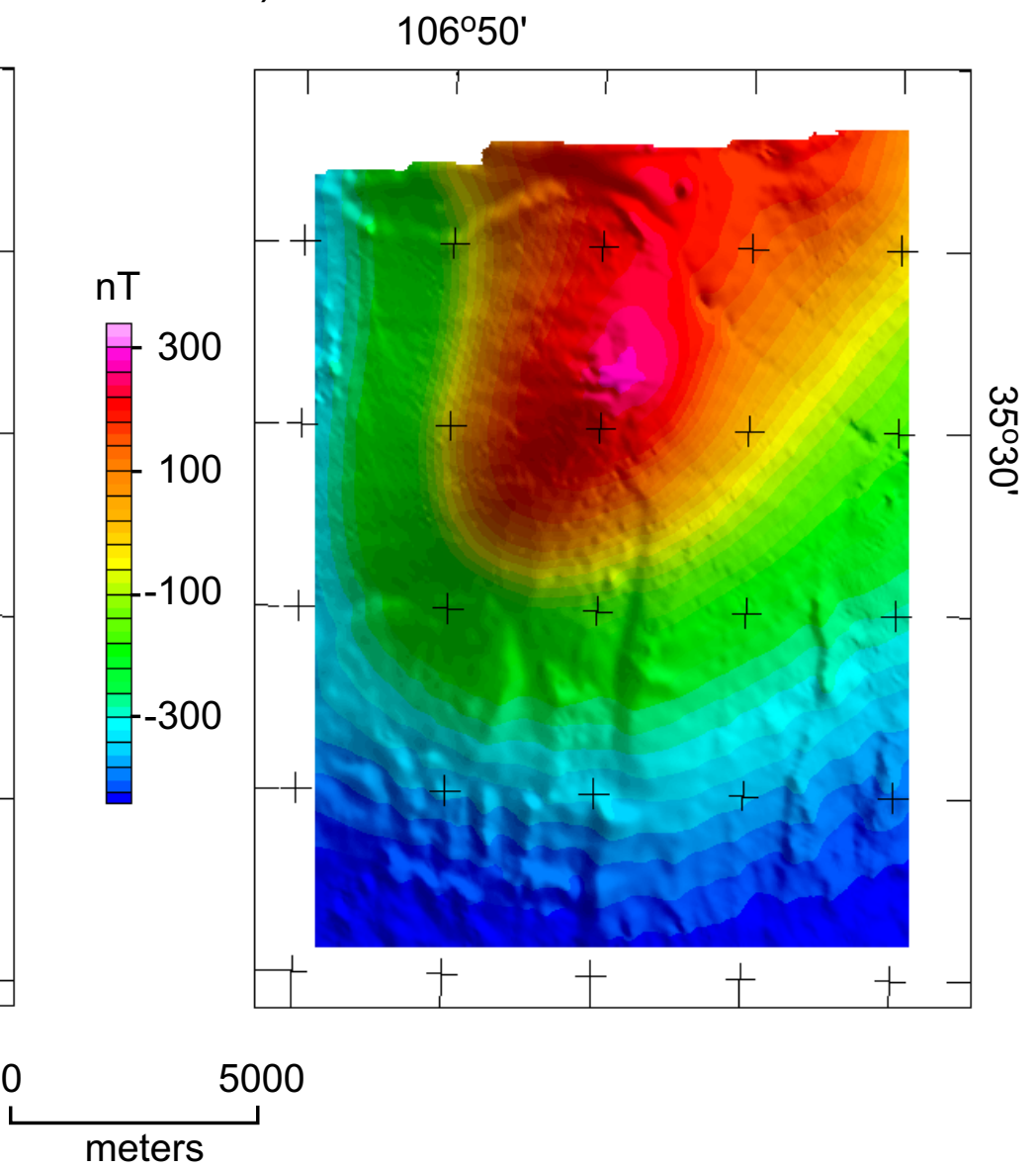

Figure 2. Comparison of a test area continued to a surface $100 \mathrm{~m}$ above ground before (a) and after (b) application of the decorrugation filter using a Blackman 11-point window. 

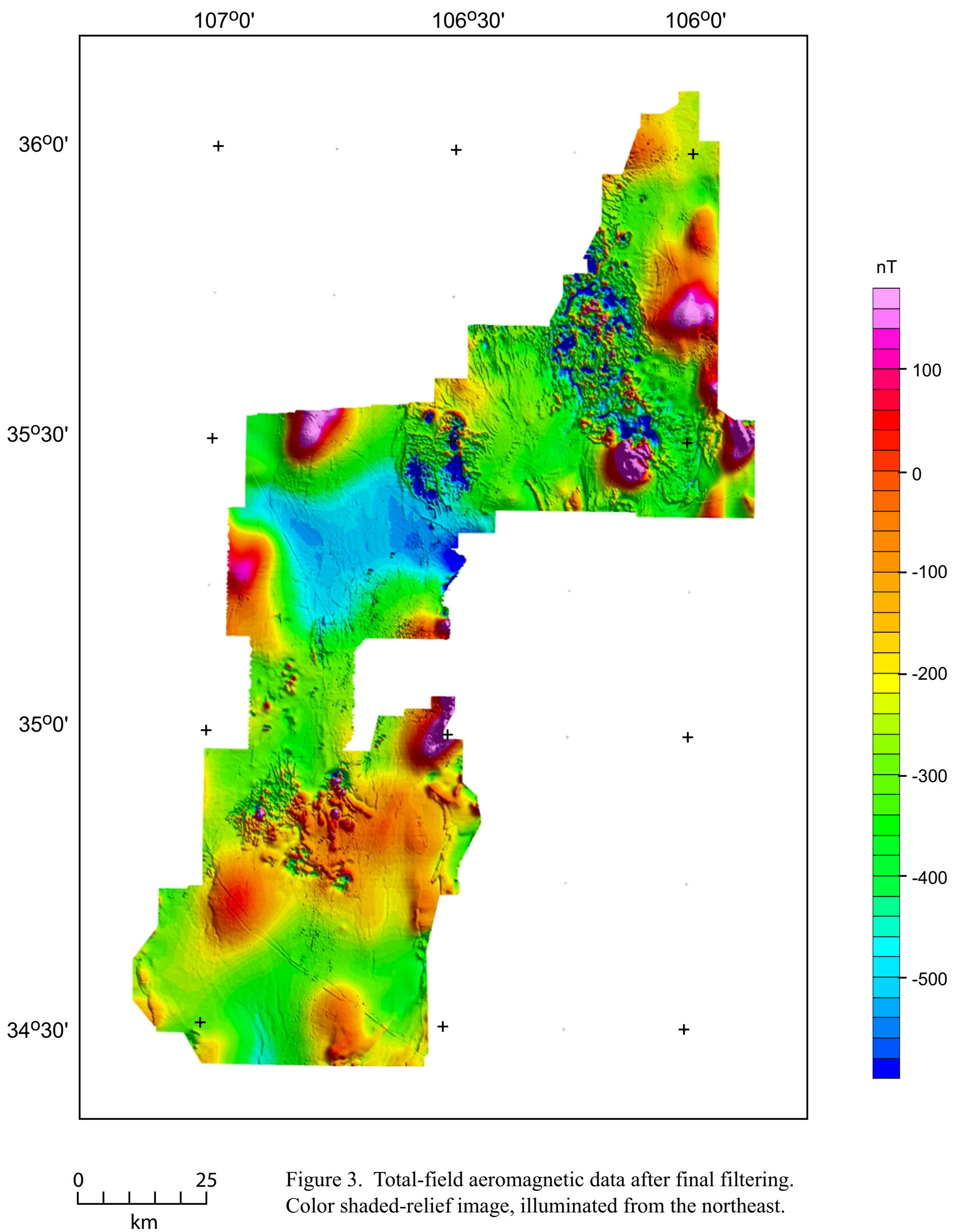

Figure 3. Total-field aeromagnetic data after final filtering. Color shaded-relief image, illuminated from the northeast. 
on the merged total-field grid. This operation generally relocates the anomalies over their magnetic sources.

To perform the reduction-to-pole transformation, we used standard FFT computer algorithms (Phillips, 1997), modified to handle large grids. However, to employ the FFT effectively, we first needed a strategy for extrapolating the irregularly shaped areas of data into a rectangular area without producing artifacts in the long wavelengths. Ultimately, we selected a subset of the New Mexico aeromagnetic grid (Kucks and others, 2001) for the surrounding fill. Though this grid was created at 1,000 ft above ground with a grid interval of $500 \mathrm{~m}$, the magnetic amplitudes and frequencies more accurately represent the surrounding magnetic environment than anything else readily available. The final totalfield grid with a $2000 \mathrm{~m}$ surrounding buffer zone containing extrapolated data were inserted into the New Mexico magnetic grid by blending the two grids in the buffer zone, insuring a smooth transition between the grids. The reduction-to-pole transform was applied to this larger grid, following the procedures of trend removal and transformation supplied in Phillips (1997). An inclination of $63^{\circ}$ and a declination of $11^{\circ}$ were assumed

for the Earth's magnetic field. Figure 4 shows the final, reduced-to-pole data for the survey areas. Figure 5 shows this reduced to the pole grid with the surrounding New Mexico data.

\section{DIGITAL FILES}

Digital files are included for (1) merged total-field aeromagnetic data observed at $100 \mathrm{~m}$ above ground, (2) reduced-to-pole aeromagnetic data observed at $100 \mathrm{~m}$ above ground, and (3) terrain clearances used to continue original data for each survey to the surface $100 \mathrm{~m}$ above ground. Grids are included for all files; images in various formats are included for the aeromagnetic data only. All files are geographically registered using the following map projection parameters: Universal transverse mercator (UTM) projection, zone 13, (central meridian $=105^{\circ} \mathrm{W}$, base latitude $\left.=0^{\circ}\right)$, North American Datum of 1927 (NAD27) with spheroid of Clarke 1866, units in meters.

The digital files are available from http://pubs.usgs.gov/of/2002/ofr-02-0205/ downloads/ and are described in Table 3. 

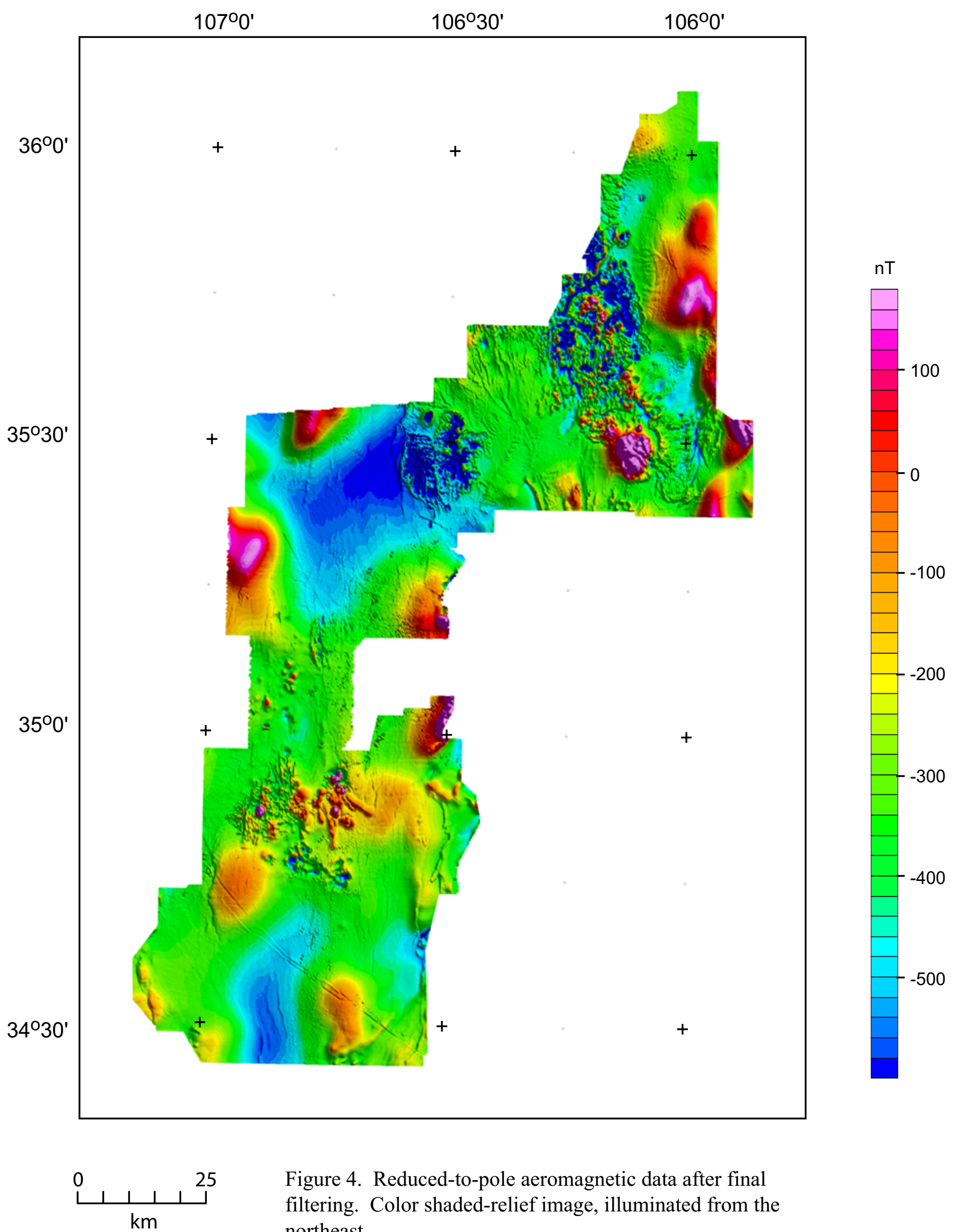

Figure 4. Reduced-to-pole aeromagnetic data after final filtering. Color shaded-relief image, illuminated from the northeast. 

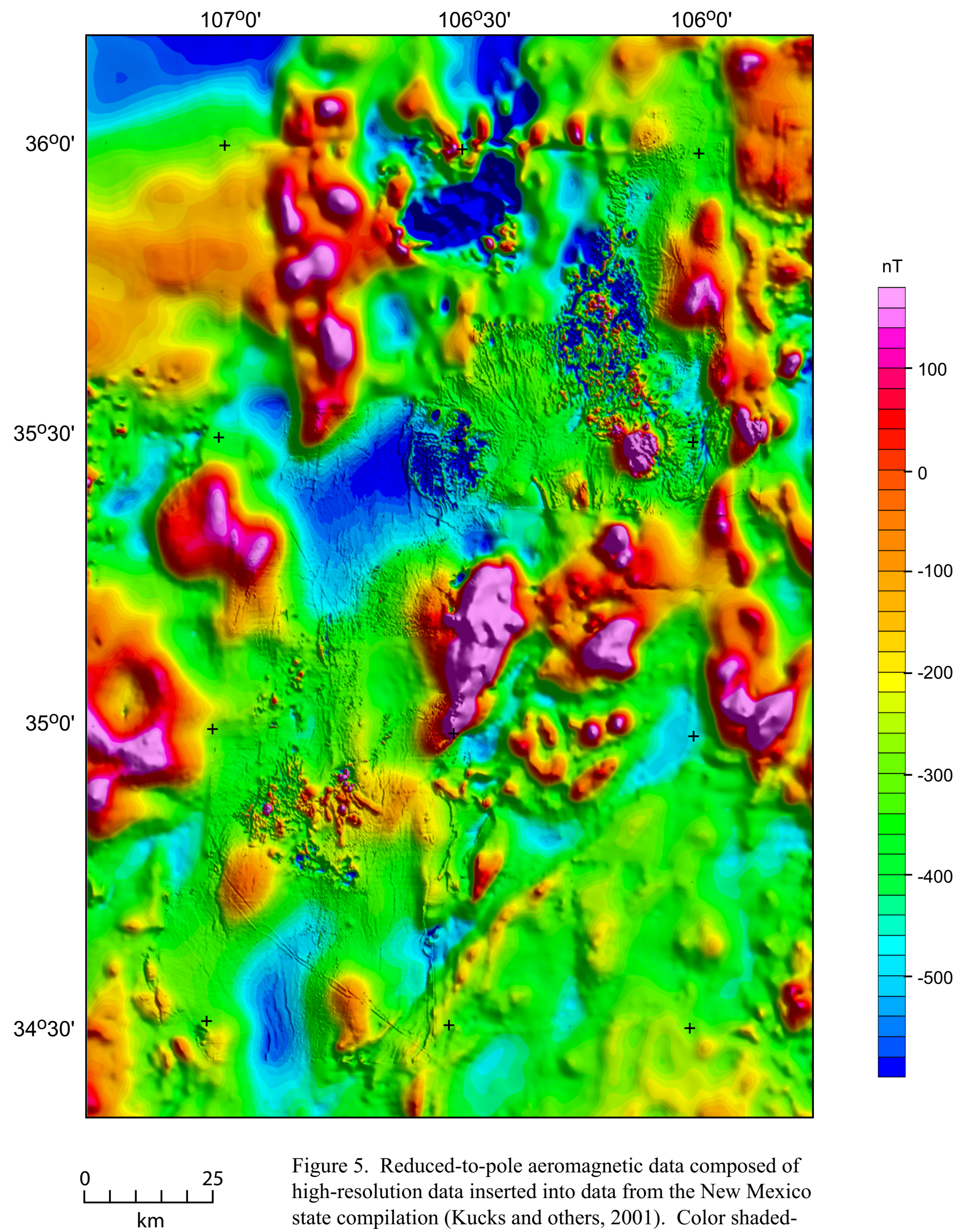

Figure 5. Reduced-to-pole aeromagnetic data composed of high-resolution data inserted into data from the New Mexico state compilation (Kucks and others, 2001). Color shadedrelief image, illuminated from the northeast. 
Table 3. Digital file descriptions.

\begin{tabular}{|l|l|l|}
\hline FILE NAME & FORMAT TYPE & DESCRIPTION \\
\hline 1readme.txt & ASCII text & $\begin{array}{l}\text { File introducing the digital files and } \\
\text { report. }\end{array}$ \\
\hline ----GRID FILES---- & ASCII text & $\begin{array}{l}\text { Description of grids with the extension } \\
\text { gxf and explanation of grid exchange } \\
\text { format }\end{array}$ \\
\hline mrgtf.gxf & Grid exchange format & $\begin{array}{l}\text { Final levelled, decorrugated, total-field } \\
\text { magnetic data on observation surface 100 } \\
\text { m above ground, merged for whole survey } \\
\text { area. }\end{array}$ \\
\hline mrgrtp.gxf & Grid exchange format & $\begin{array}{l}\text { Final levelled, decorrugated, reduced-to- } \\
\text { pole magnetic data on observation surface } \\
100 \text { m above ground, merged for whole } \\
\text { survey area. }\end{array}$ \\
\hline mrgterr.gxf & Grid exchange format & $\begin{array}{l}\text { Merged terrain data used for the whole } \\
\text { area (see report for details). }\end{array}$ \\
\hline tcaw.gxf & Grid exchange format & $\begin{array}{l}\text { Radar-altimeter measurements for the } \\
\text { Albuquerque west survey in meters, used } \\
\text { to continue original data (USGS and Sial, } \\
\text { Ltd., 1997) to the 100-m surface. }\end{array}$ \\
\hline tcbe.gxf & Grid exchange format & $\begin{array}{l}\text { Terrain clearance for the Belen survey } \\
\text { constructed from GPS elevations and } \\
\text { terrain data, used to continue original data } \\
\text { (USGS and others, 1999) to the 100-m } \\
\text { surface. }\end{array}$ \\
\hline tcrr.gxf & Grid exchange format & $\begin{array}{l}\text { Terrain clearance for the Cochiti survey } \\
\text { constructed from GPS elevations and } \\
\text { terrain data, used to continue original data } \\
\text { (USGS and others, 1999) to the 100-m } \\
\text { surface. }\end{array}$ \\
\hline tcco.gxf & $\begin{array}{l}\text { Terrain clearance for the Isleta-Kirtland } \\
\text { survey constructed from GPS elevations } \\
\text { and terrain data, used to continue original } \\
\text { data (USGS and Sander Geophysics, } \\
\text { 1998) to the 100-m surface. }\end{array}$ \\
\hline Grid exchange format & $\begin{array}{l}\text { Radar-altimeter measurements for the Rio } \\
\text { Rancho survey in meters, used to continue } \\
\text { original data (USGS and Sial, Ltd., 1997) } \\
\text { to the 100-m surface. }\end{array}$ \\
\hline & Grid exchange format & \\
& & \\
& &
\end{tabular}


Table 3. Digital file descriptions - CONTINUED

\begin{tabular}{|c|c|c|}
\hline tcss.gxf & Grid exchange format & $\begin{array}{l}\text { Terrain clearance for the Sandoval-Santa } \\
\text { Fe survey constructed from GPS } \\
\text { elevations and terrain data, used to } \\
\text { continue original data (USGS and others, } \\
1999 \text { ) to the } 100-\mathrm{m} \text { surface. }\end{array}$ \\
\hline \multicolumn{3}{|c|}{----IMAGE FILES---- } \\
\hline imginfo.txt & ASCII text & $\begin{array}{l}\text { Description of the files and their formats } \\
\text { containing color shaded-relief images of } \\
\text { the final aeromagnetic grids. }\end{array}$ \\
\hline mrgtfim.tif & Tagged image format & $\begin{array}{l}\text { Color shaded-relief image final, merged } \\
\text { total-field aeromagnetic data without } \\
\text { scales or text annotation for import by } \\
\text { many graphics packages. When paired } \\
\text { with mrgtfim.tfw in the same directory, } \\
\text { the file can be imported into ARC/INFO } \\
\text { and ARC/VIEW }\end{array}$ \\
\hline mrgtfim.tfw & Geotif ASCII header file & See mrgtfim.tif \\
\hline mrgrtpim.tif & Tagged image format & $\begin{array}{l}\text { Color shaded-relief image of the final, } \\
\text { merged reduced-to-pole aeromagnetic } \\
\text { data without scales or text annotation for } \\
\text { import by many graphics packages. When } \\
\text { paired with mrgrtpim.tfw in the same } \\
\text { directory, the file can be imported into } \\
\text { ARC/INFO and ARC/VIEW }\end{array}$ \\
\hline mrgrtpim.tfw & Geotif ASCII header file & See mrgrtpim.tif \\
\hline mrgtfim.pdf & Portable document format & $\begin{array}{l}\text { Color shaded-relief image of the final, } \\
\text { merged total-field aeromagnetic data with } \\
\text { map and color scales and latitude/ } \\
\text { longitude labels for Adobe Acrobat } \\
\text { Reader, which is available at no charge } \\
\text { from www.adobe.com. Original plot is at } \\
\text { 1:175,000 scale, which will give a } 30 " \\
\text { wide by } 44 " \text { high plot if no scaling is } \\
\text { applied. }\end{array}$ \\
\hline mrgrtpim.pdf & Portable document format & $\begin{array}{l}\text { Color shaded-relief image of the final, } \\
\text { merged reduced-to-pole aeromagnetic } \\
\text { data with map and color scales and } \\
\text { latitude/longitude labels for Adobe } \\
\text { Acrobat Reader, which is available at no } \\
\text { charge from www.adobe.com. Original } \\
\text { plot is at 1:175,000 scale, which will give } \\
\text { a } 30 " \text { wide by } 44 " \text { high plot if no scaling } \\
\text { is applied. }\end{array}$ \\
\hline
\end{tabular}


Table 3. Digital file descriptions - CONTINUED

\begin{tabular}{|c|c|c|}
\hline \multicolumn{2}{|c|}{----MISCELLANEOUS FILES---- } & \\
\hline 1report.pdf & Portable document format & $\begin{array}{l}\text { A file containing the text of this report, } \\
\text { with figures included. }\end{array}$ \\
\hline
\end{tabular}

\section{REFERENCES CITED}

Bartolino, J.R., and Cole, J.C., 2002, Ground-water resources of the Middle Rio Grande Basin, New Mexico: U.S. Geological Survey Circular 1222, in press.

Blakely, R. J., 1995, Potential theory in gravity and magnetic applications: Cambridge University Press, $441 \mathrm{p}$.

Cordell, Lindrith, 1985, Techniques, applications, and problems of analytical continuation of New Mexico aeromagnetic data between arbitrary surfaces of very high relief: Proceedings, Internat. mtg. on potential fields in rugged topography, Université de Lausanne, Switzerland, July-August, 1985, 96-101.

Grauch, V. J. S., 1999, Principal features of high-resolution aeromagnetic data collected near Albuquerque, New Mexico: New Mexico Geological Society Guidebook, 50, $115-118$.

Grauch, V. J. S., 2001, High-resolution aeromagnetic data, a new tool for mapping intrabasinal faults: An example from the Albuquerque basin, New Mexico: Geology, v. 29, p. 367-370.

Grauch, V. J. S., Hudson, M. R., and Minor, S. A., 2001, Aeromagnetic expression of faults that offset basin fill, Albuquerque basin, New Mexico: Geophysics, v. 66, p. 707-720.

Hester, D.J., 1998, USGS Middle Rio Grande Basin Study develops terrain data, in The Map Legend Spring/Summer 1998 newsletter, New Mexico Geographic Information Council, Volume 9, Issue 2, p.3.

Kelley, V. C., 1977, Geology of Albuquerque Basin, New Mexico: New Mexico Bureau of Mines and Mineral Resources Memoir 33, 59 p., 2 plates.

Kucks, R. P., Hill, P. L., and Heywood, C. E., 2001, New Mexico aeromagnetic and gravity maps and data: A web site for distribution of data, version 1.0: U. S. Geological Survey Open-File Report 01-0061, available at http://greenwood.cr.usgs.gov/pub/open-file-reports/ofr-01-0061.

May, S. J., and Russell, L. R., 1994, Thickness of the syn-rift Santa Fe Group in the Albuquerque Basin and its relation to structural style: Geological Society of America Special Paper 291, p. 113-123. 
Nettleton, L. L., 1971, Elementary gravity and magnetics for geologists and seismologists: Society of Exploration Geophysicists Monograph series, no. 1, 121 p.

Oppenheim, A. V., and Schafer, R. W., 1975, Digital signal processing, 1st edition: Prentice-Hall, Inc., 585 p.

Phillips, J. D., 1997, Potential-field geophysical software for the PC, version 2.2: U. S. Geol. Surv. Open-File Report 97-725. Available from $\mathrm{ftp}$ //greenwood.cr.usgs.gov/pub/open-file-reports/ofr-97-0725/pfofr.htm

Reid, A. B., 1980, Aeromagnetic survey design: Geophysics, v. 45, p. 973-976.

Thorn, C. R., McAda, D. P., and Kernodle, J. M., 1993, Geohydrologic framework and hydrologic conditions in the Albuquerque Basin, central New Mexico: U. S. Geological Survey Water-Resources Investigations Report 93-4149, 106 p.,1 pl.

Urquhart, T., 1988, Decorrugation of enhanced magnetic field maps: Expanded Abstracts and Biographies, Society of Exploration Geophysicists 58th annual meeting, Anaheim, CA, 1988, p. 371-372.

U.S. Geological Survey, 2000, US GeoData Digital Elevation Models, USGS Factsheet FS 040-00, http://mac.usgs.gov/mac/isb/pubs/factsheets/fs04000.html.

U. S. Geological Survey and Sander Geophysics, 1998, Digital data from the IsletaKirtland aeromagnetic survey, collected south of Albuquerque, New Mexico: U.S. Geological Survey Open-File Report 98-341, 1 CD-ROM.

U. S. Geological Survey, Sander Geophysics, Ltd., and Geoterrex, 1999, Digital data from the Sandoval-Santa Fe, Belen, and Cochiti aeromagnetic surveys, covering areas in Sandoval, Santa Fe, Rio Arriba, Valencia, and Socorro Counties, New Mexico: U. S. Geological Survey Open-File Report 99-404.

U. S. Geological Survey and SIAL Geosciences, Inc., 1997, Description of digital aeromagnetic data collected north and west of Albuquerque, New Mexico U. S. Geological Survey Open-File Report 97-286, 40 pp., digital files available at http://greenwood.cr.usgs.gov/pub/open-file-reports/ofr-97-0286/.

Webring, M., 1981, MINC: A gridding program based on minimum curvature: U. S. Geological Survey Open-file Report 81-1224, 40 p. 